\title{
Poemas
}

Ytzel Maya*

\section{QUÍMICA DEL AIRE}

Los objetos en el espejo están más cerca de lo que aparentan, dice un viejo proverbio cochista que casi siempre está grabado en los espejos para advertir a los usuarios que lo que se refleja de la realidad no es inmediato. Estos espejos, estas fotografías paulatinas del camino, se nos revelan como lugares equidistantes y transitorios.

$$
*
$$

[¿Qué tan lejos estamos de todo?]

Tal vez lo que nos advierten los ojos es tan solo un pedazo de lo que nos separa del mundo, una porción de nada. La distancia es un imaginario. Estoy segura de que esta propiedad que le han dotado los espejos a los vehículos es propia de la movilización terrestre, pero ¿cómo calculan la distancia del otro los pilotos en el aire sin estos espejos?, ¿acaso el reflejo del camino no es más que desplazamiento sobre un suelo firme?

$$
*
$$

La imagen completa del planeta sugiere el conjunto inseparable del cielo y la tierra, pero la movilización en cada uno funciona de maneras diferentes. De cualquier forma, ambas superficies, inasibles o no, son inacabables.

$*$

[¿Cómo medimos la distancia en el aire si no existen los caminos?]

*Ytzel Maya (Ciudad de México, 1993) ha publicado en revistas como Tierra Adentro y Punto en Línea. Actualmente es editora en el Instituto Nacional de Lenguas Indígenas. 


\section{Ley}

La distancia se define en matemáticas como la separación de dos puntos que equivale a la longitud del segmento que los une. Pero la distancia palpable, la que se recorre y se camina todos los días, puede medirse por la lejanía o la cercanía entre dos cuerpos, dos objetos o dos lugares. Es decir, siempre tenemos cierta distancia del otro. La distancia es lo que nos diferencia de los demás objetos o personas en el mundo. Y, aunque la intriga de las investigaciones radique principalmente en medir las superficies de la tierra, el cielo no puede desprenderse del aire:

depende de él, como un elemento inequívoco de su propia constitución.

\section{Ley del nitrógeno}

De las imágenes que guardo en mi memoria, las más bellas le pertenecen al aire, como la primera vez que vi nevar. A pesar de que el sonido de la lluvia es muy particular, la nieve tiene un cierto eco muy diferente. Despierto con la sensación de la tormenta, abro la ventana y la madera del puente está congelada, convive a la fuerza con la nieve que se sigue amontonando entre los tablones y que cubre, al menos, cinco centímetros de las columnas bajo el barandal. Los copos que se van imprimiendo sobre el piso siguen el patrón designado por las nubes: un núcleo que hilvana sus vértices y aristas para dar paso a la forma, una especie de huella digital que deja el frío. A esta forma clásica que la mente tiene de asociar a los copos de nieve con una imagen se le llama dendrita, cada una es diferente a otra. Una dendrita se caracteriza porque su estructura es una repetición de sí misma, todos sus ejes son una reproducción geométrica exacta. Pero las dendritas también designan la parte de las células del cerebro que se ramifican hasta las terminaciones nerviosas presentes en la neuronas. Su parecido no es casualidad: los copos de nieve son la memoria del invierno, fragmentada e irrepetible. 


\section{Ley del nitrógeno sobre la somnolencia}

$\mathrm{Al}$ arte de moverse por el aire le hemos llamado volar: los sueños sobre esto son persistentes. En el buscador de Google, podemos encontrar las preguntas: ¿qué significa soñar que vuelo?, ¿por qué, en el sueño, vuelo sobre el mar?, ¿qué significa volar así, de noche, o en avioneta o sobre una escoba? Quizá todo empieza con un salto.

Existen diferentes formas de volar en el sueño.

Personalmente, sigo una estructura icarezca del movimiento. Desde que recuerdo, sueño que vuelo: la lógica anatómica consiste en usar mis brazos a manera de alas y mi cuerpo, horizontal, rompe el aire para poderme elevar y avanzar hacia donde quiero mientras bato estas alas sin plumas con una facilidad azarosa. Pero primero el salto: un impulso primitivo, quizá, y esencial para poderlo lograr.

Imagino que uno de los sueños recurrentes de Franz Reichelt, un sastre francoaustriaco que intentó volar y se aventó de la Torre Eiffel, era el de volar. Lo imagino soñando con esto todos los días. Lo imagino caminando por París y viendo por encima de todos la magnitud de la tierra. Casi no hay fotografías sobre esto, pero se conserva un video que grabaron el 4 de febrero de 1912, el día que decidió saltar. La última imagen que grabó el camarógrafo es la de una persona midiendo la profundidad del hoyo que dejó el impacto de Reichelt sobre el suelo.

El sueño es un lugar seguro. $\mathrm{O}$ al menos pretende serlo. Las personas que vuelan en el sueño suelen hacerlo en levitación o en una elevación vertical que nunca se detiene. 


\section{Segunda ley}

La definición de distancia, en física, es diferente. Implica desplazamiento y trayectoria. Para calcularla es necesario saber el tiempo que tardó en recorrerse y la velocidad con la que se hizo. Resulta afanoso diferenciar la distancia matemática de la física, pero las virtudes del análisis nos dotan de posibilidades para descomponer los detalles de por qué caminamos o por qué esta pulsión por volar, ya sea que el recorrido se mide por la distancia de un punto a otro, o porque este recorrido necesita de un inicio y un final específico.

\section{Segunda ley del oxígeno}

Para que una llama siga encendida necesita aire. El comportamiento fisicoquímico del fuego es una acción casi poética: el aire que se encuentra alrededor de las moléculas o partículas calientes disminuye la densidad y tiende a flotar sobre el aire más frío. Así, el aire adopta la forma liminal de la llama y, en el caso particular del fuego de estado sólido, el aire caliente viaja hacia arriba a tal velocidad, conservando su forma pero obliterando todos los elementos que lo conforman, que empuja incluso partículas pesadas de combustible en la misma dirección, aún calientes y brillantes, que van bajando de temperatura al igual que el aire circundante, dejando de brillar y tornándose generalmente negro; el aire, al enfriarse, empieza a bajar de velocidad, a tal punto que ya no puede empujar las partículas hacia arriba. Estas empiezan, si pesan más que el aire, a levitar sin subir, para luego caer de nuevo a tierra.

$*$

Los fuegos artificiales son otra forma del aire. Estos se rigen por el principio de la línea punteada del fuego.

$*$

De las imágenes que guardo en mi memoria, las más bellas le pertenecen a la luminosidad del fuego, como la vez que uno artificial explotó por accidente enfrente de mí y un domo de luz me cubrió por una fracción de segundo. Tal vez, como describe Anne Carson entre la multitud desde su carta en The 
anthropology of water, los fuegos artificiales, tambaleantes e irresistibles, parecidos al amor humano, son también una refracción del cielo, casi como imitando las estrellas que caen cuando mueren.

\section{Tercera ley}

Estudiar la distancia es imaginar todos los caminos posibles a lo largo y ancho de todo el espacio ilimitado en el mundo. No bastarán las fórmulas ni los cálculos para medir todas las veredas ni la consistencia ni los caminos del aire, estoy segura. 